\title{
HLA-DR antigens in systemic lupus erythematosus: association with specificity of autoantibody responses to nuclear antigens
}

\author{
JOSEF S SMOLEN, ${ }^{1}$ JOHN H KLIPPEL ${ }^{4}$ EDWARD PENNER ${ }^{2}$ \\ MORRIS REICHLIN, 8 ALFRED D STEINBERG, ${ }^{4}$ THOMAS M CHUSED, ${ }^{5}$ \\ OTHMAR SCHERAK, ${ }^{1}$ WINFRIED GRANINGER, \\ ENGELBERT HARTTER, ${ }^{1}$ CHRISTOPH C ZIELINSKI, ${ }^{\text {AXEL WOLF, }}$ \\ RICHARD J DAVEY, ${ }^{6}$ DEAN L MANN, ${ }^{7}$ AND WOLFGANG R MAYR ${ }^{3}$
}

From the ${ }^{1} 2$ nd Department of Internal Medicine, the ${ }^{2} 1$ st Department of Gastroenterology, and the ${ }^{3}$ Institute of Blood Group Serology, University of Vienna, Vienna, Austria; the ${ }^{4}$ Arthritis and Rheumatism Branch, National Institute of Arthritis, Diabetes, Digestive and Kidney Diseases National Institutes of Health, Bethesda, Maryland, USA: the ${ }^{5}$ Laboratory of Microbial Immunology, National Institute of Allergy and Infectious Diseases, Bethesda, and the ${ }^{6}$ Blood Bank, National Institutes of Health, Bethesda; the ${ }^{7}$ Laboratory of Human Carcinogenesis, National Cancer Institute, Bethesda; and the ${ }^{8}$ Arthritis and Immunology Laboratory, Oklahoma Medical Research Foundation, Oklahoma City, Oklahoma, USA

SUMMARY HLA-DR antigens and autoantibodies to the nuclear or cytoplasmic antigens Ro/SSA, La/SSB, Sm, and RNP were determined in North American and Austrian patients with systemic lupus erythematosus (SLE). Analysis of the association of antibodies to these ribonucleic acid (RNA)-protein antigens with HLA-DR antigens showed that HLA-DR3 was related to the presence of anti-Ro/SSA or anti-La/SSB, or both. In contrast, anti-Sm or antiRNP, or both were associated with HLA-DR4. HLA-DR5 was associated with absence of these autoantibodies. The data extend evidence for the complexity and heterogeneity of SLE. Moreover, they indicate that, in SLE, genes linked to those coding for HLA-DR antigens, are related to the specifity of autoantibody responses rather than to the primary immunological abnormalities of this disorder.

Key words: antinuclear antibodies, Ro, La, Sm, RNP.

The diversity of autoantibodies in patients with systemic lupus erythematosus (SLE) is unexplained. In addition to antibodies to deoxyribose nucleic acid (DNA), precipitating antibodies to a variety of nuclear antigens have been described. ${ }^{12}$ These antibodies are directed against ribonucleoprotein particles which contain small nuclear RNA. Among them, the most common are those to Ro (SSA) antigen. Antibodies to La (SSB) almost invariably occur together with antibodies to Ro/SSA. ${ }^{34}$

Antibodies to $\mathrm{Sm}$ are currently regarded as the most specific, though insensitive, marker of SLE.

Accepted for publication 16 December 1986.

Correspondence to Dr Josef S Smolen. 2nd Department of Internal Medicine. University of Vienna. Garnisongasse 13. A-1090 Vienna. Austria.
Antibodies to nuclear ribonucleoprotein (RNP) are also observed in SLE but they are present in much higher titres in sera from patients with mixed connective tissue disease (MCTD). ${ }^{5}$

Recent investigations have indicated that anti$\mathrm{Ro} / \mathrm{La}$ and anti-Sm/RNP represent two families of autoantibody systems. ${ }^{3} 4$ 6-9 This evidence from molecular analyses has a biological correlate: SLE patients with anti-Ro may have distinct clinical features $^{10-13}$ which are different from those of SLE patients with anti-Sm or anti-RNP. ${ }^{14-16}$ Moreover, non-SLE patients with anti-Ro or anti-La usually have primary Sjögren's syndrome, whereas nonSLE patients with anti-RNP primarily suffer from MCTD. ${ }^{12} 51718$

Immune responses to autoantigens, like those to conventional antigens, are controlled by the major 
histocompatibility complex (MHC). ${ }^{19}$ Several autoimmune disorders have been found associated with genes of the MHC, some even with two or more such genes, ${ }^{19}$ and SLE is one example. ${ }^{20-22}$

The reason for such associations has not been fully elucidated as yet. Searching for potential associations between autoantibody production and MHC genes in SLE, we have investigated patients with SLE for both HLA antigens and circulating antibodies to RNA-protein antigens. The results suggest that expression of these autoantibodies in SLE is controlled by genes closely linked to D locus alleles of the MHC and that these associations are different for different autoantibody specificities.

\section{Patients, materials, and methods}

\section{PATIENT POPULATION}

One hundred Caucasian patients (93 female, seven male) with systemic lupus erythematosus according to the American Rheumatism Association criteria $^{23}{ }^{24}$ were studied; thirty six were American and 64 Austrian. The age range at the time of the study was 17-72 years.

DETERMINATION OF HLA ANTIGENS

Fourteen antigens governed by HLA-A, 17 by HLA-B, and five by HLA-C were determined using the standard National Institute of Health (NIH) microlymphocytotoxicity assay. Each antigen was identified by at least three separate sera. The sera used have been shown to bear the same specificities as the standard sera of the 4th to 8th Histocompatibility Workshops. Moreover, these sera did not contain antibodies to B cell antigens.

Reactivity was regarded as positive if at least three sera used to define a specific antigen lysed $>80 \%$ of the cells. Six HLA-DR antigens (HLADR1-5 and 7) were analysed for HLA-DR typing by the two colour fluorescence method. ${ }^{25}$ The antisera employed have been shown to bear the same specificities as those of the 7th to 9th Histocompatibility Workshops.

The data obtained in the patient population were compared with those of control populations. Control data for American Caucasians were taken from the data obtained at the 8th Histocompatibility Workshop. ${ }^{26}$ Control data for the Austrians were obtained by local tissue typing of 450 healthy individuals (for HLA-A, B, C typing) or 125 healthy persons (for HLA-DR typing). Since the antigen frequencies in these latter control populations, ${ }^{27}$ which were obtained using sera of the Histocompatibility Workshops, did not differ $(p>0 \cdot 1)$ from the frequencies in other Middle European populations ${ }^{26}$ or from the Workshop data for American Cauca- sians, data of healthy American and Austriar? Caucasians were combined $(n=1270)$ as controf. populations. ${ }^{28}$

DETERMINATION OF ANTIBODIES TO R N A - PROTEIN ANTIGENS

All patients had antinuclear antibodies as deter⿸厃㔾 mined by indirect immunofluorescence on mouse of rat liver sections. All but three patients had ant: bodies to double stranded DNA as determined $b \vec{\rho}$ the Farr technique. Antibodies to RNA-protein antigens were analysed by immunodiffusion is Oklahoma (US patients) and by immunodiffusiow and the Western blot technique in Vienna (U९ patients and Austrian patients) as previousi $(\vec{m}$ described. ${ }^{29}{ }^{30}$ When discrepancies occurred result? obtained by blotting were used for further analysescr The antibody specificities analysed were: anti-Sm $\odot$ anti-RNP, anti-Ro/SSA, and anti-La/SSB .

STATISTICAL ANALYSIS

Statistical analysis of the HLA antigen frequencie was performed by $\chi^{2}$ or Fisher's exact test ${ }^{2 x}$; the values obtained were corrected for the number oథ antigen specificities investigated $\left(\mathrm{p}_{\mathrm{c}}\right){ }^{28.31}$

\section{Results}

FREQUENCY OF HLA ANTIGENS IN SLE

The frequencies of HLA-DR antigens in the patien populations studied are shown in the first line of Table 1. When compared with control dat $(n=1270)$ there was a significantly increased fre? quency in patients with SLE of both HLA-DR2 an DR3 (DR2: $41 \%$ in SLE $v 25 \%$ in controls $\mathrm{p}<0.0005, \mathrm{p}_{\mathrm{c}}<0.003$; DR3: $39 \%$ in SLE $v 22 \%$ i controls, $\left.\mathrm{p}<0.0002, \mathrm{p}_{\mathrm{c}}<0.001\right)$. As with the US ang Austrian controls, frequencies of HLA antigens i⿱ Austrian and Caucasian US patients did not diffe? significantly from each other $(p>0 \cdot 1$; data nof shown), and the two populations were thereforo combined.

CORRELATIONBETWEEN HLA-DRANTIGENSN AND PRECIPITATING ANTIBODIES TO

RNA - PROTEIN ANTIGENS

The distribution of autoantibodies to RNA-proteif antigens is shown in Table 1 and related to HLA-DR antigens. This allowed for a detailed analysis of potential associations between the pre्ष sence of MHC encoded antigens and the occurrence of particular types of precipitating antibodies. Pao tients were divided into four groups: $(a)$ patiente with anti-La (SSB), anti-Ro (SSA), or both (termeg group I or 'anti-Ro/La'); (b) patients with anti-Sng anti-RNP, or both (termed group II or ant? Sm/RNP'); (c) patients with anti-Ro and anti-Sm 
Table 1 Distribution of HLA-DR antigens and autoantibodies to RNA-protein antigens in 100 patients with SLE

\begin{tabular}{|c|c|c|c|c|c|c|c|c|}
\hline $\begin{array}{l}\text { Autoantibody } \\
\text { Specificity }\end{array}$ & $\begin{array}{l}\text { Patients } \\
\text { group }\end{array}$ & $n$ & $D R I$ & $D R 2$ & $D R 3$ & $D R 4$ & DR5 & $D R 7$ \\
\hline - & All SLE & 100 & 18 & 41 & 39 & 17 & 18 & 21 \\
\hline Anti-Ro/La* & I & 32 & $\begin{array}{c}5 \\
(16 \%) \dagger\end{array}$ & $\begin{array}{l}15 \\
(47 \%)\end{array}$ & $\begin{array}{c}19 \\
(59 \%)\end{array}$ & $\underset{(6 \%)}{2}$ & $\begin{array}{l}1 \\
(3 \%)\end{array}$ & $\begin{array}{c}6 \\
(19 \%)\end{array}$ \\
\hline Anti-Sm/RNP* & II & 12 & $\begin{array}{c}4 \\
(33 \%)\end{array}$ & $\begin{array}{c}6 \\
(50 \%)\end{array}$ & $\begin{array}{c}2 \\
(17 \%)\end{array}$ & $\begin{array}{c}6 \\
(50 \%)\end{array}$ & $\begin{array}{l}1 \\
(8 \%)\end{array}$ & $\begin{array}{c}1 \\
(8 \%)\end{array}$ \\
\hline Anti-Ro/Sm/RNP* & III & 6 & $\begin{array}{c}2 \\
(33 \%)\end{array}$ & $\begin{array}{c}3 \\
(50 \%)\end{array}$ & $\begin{array}{c}3 \\
(50 \%)\end{array}$ & $\begin{array}{c}1 \\
(17 \%)\end{array}$ & $\begin{array}{l}0 \\
(0 \%)\end{array}$ & $\begin{array}{c}1 \\
(17 \%)\end{array}$ \\
\hline None $^{*}$ & IV & 50 & $\begin{array}{c}7 \\
(14 \%)\end{array}$ & $\begin{array}{l}17 \\
(34 \%)\end{array}$ & $\begin{array}{l}15 \\
(30 \%)\end{array}$ & $\begin{array}{c}8 \\
(16 \%)\end{array}$ & $\begin{array}{l}16 \\
(32 \%)\end{array}$ & $\begin{array}{l}13 \\
(26 \%)\end{array}$ \\
\hline- & None & $1270 \div$ & $\begin{array}{l}258 \\
(20 \%)\end{array}$ & $\begin{array}{l}315 \\
(25 \%)\end{array}$ & $\begin{array}{l}274 \\
(22 \%)\end{array}$ & $\begin{array}{l}342 \\
(27 \%)\end{array}$ & $\begin{array}{l}255 \\
(20 \%)\end{array}$ & $\begin{array}{l}303 \\
(24 \%)\end{array}$ \\
\hline
\end{tabular}

${ }^{*}$ For detailed definition see text.

+Percentage of patients analysed in the respective line.

†Frequencies in control population according to references 26 and 27.

and/or anti-RNP (termed group III or 'antiRo/Sm/RNP'); and (d) patients with none of the above (termed group IV or 'none' or 'no antiRo/Sm/RNP'). As discussed above, molecular analyses have shown close similarities between the Ro and the La antigens and between the Sm and the RNP antigens respectively. ${ }^{346-9}$ Therefore we sought to distinguish between antibody responses to these two different, non-cross-reactive nucleoprotein families. Since several patients had antibodies to both $\mathrm{Ro} / \mathrm{La}$ and $\mathrm{Sm} / \mathrm{RNP}$ we grouped them separately (group III) for the analyses.

\section{ASSOCIATION OF DIFFERENT HLA - DR \\ ANTIGENS WITH ANTIBODIES TORO/La AND S m/R N P}

Nineteen of the 32 patients with anti-Ro/La (group I, 59\%), but only 17 of 62 patients (groups II plus IV) without anti-Ro/La (27\%) had HLA-DR3 (Table 1) $\left(\mathrm{p}<0.002, \mathrm{p}_{\mathrm{c}}<0.015\right)$. No other significant differences concerning the other HLA-DR antigens were observed between the two populations.

Next, HLA-DR antigen distributions were related to the presence of anti-Sm/RNP. Two interesting observations emerged: firstly, only two of these 12 patients $(17 \%)$ had HLA-DR3, though $50 \%$ were positive for DR2; secondly, in half of these patients, but in only $12 \%$ of all patients without anti-Sm/RNP (groups I plus IV), HLA-DR4 was present $\left(\mathrm{p} \ll 0.01, \mathrm{p}_{\mathrm{c}}<0.05\right)$. In addition, $33 \%$ of both group II and group III patients, but only $13 \%$ and $14 \%$ respectively, of group I and group IV patients, had HLA-DR1; this difference was not significant statistically. When the frequency of DR1 and DR4 were considered together, nine of 12 patients with antiSm-RNP (75\%), but only 22 of 82 patients without anti-Sm/RNP $(27 \%)$, had DR1 or DR4, or both $\left(p<0.001, p_{c}<0.02\right.$, corrected for the number of possible pairs of DR antigens). Moreover, $50 \%$ of the patients with both anti-Ro and anti-Sm/RNP (group III) had HLA-DR1 or DR4, or both.

LACK OF ASSOCIATION OF SLE WITH HLA-DR ANTIGENS IN PATIENTS WITHOUT ANTIBODIES TO RNA-PROTEIN ANTIGENS When the frequency of HLA-DR antigens in the 50 patients without antibodies to Ro, La, Sm, or RNP (Table 1, group IV) was compared with that of healthy controls the differences for all HLA-DR antigens, including HLA-DR2 and DR3, lacked significance. In contrast, HLA-DR3 was markedly increased $\left(p_{c}<0.00001\right)$ in anti-Ro/La (but not antiSm/RNP) patients, and HLA-DR2, present in approximately $50 \%$ of all group I, II, and III patients, was also increased in frequency when compared with the control population $\left(p_{c}<0.002\right)$. Of interest, $32 \%$ of the patients without antibodies to Ro, La, Sm, or RNP were found to have HLA-DR5 as opposed to only $4 \%$ of individuals with at least one of these autoantibodies (Table 1 , $\left.\mathrm{p}=0.0004, \mathrm{p}_{\mathrm{c}}<0.0025\right)$.

\section{Discussion}

In this Caucasian population of North American and Middle European SLE patients a significantly increased frequency of HLA-DR3 and of HLA-DR2 was observed. These significant associations, however, were seen only among patients with antibodies to the RNA-protein antigens Ro, La, Sm, or RNP. This lack of association in anti-Ro/La/Sm/RNP negative patients was not due a low patient number, since the antibody negative group comprised exactly half of the total study population. Rather, these data 
indicate that the mechanisms underlying the pathogenesis of SLE disease are not necessarily MHC associated.

Analysis of the relation between antibodies to RNA-protein and HLA antigens showed that the association of HLA-DR3 with SLE in the total patient population was predominantly due to its increased frequency in one subgroup of patients, namely those with the autoantibodies anti-Ro/SSA and $\mathrm{La} / \mathrm{SSB}$. In contrast, DR3 frequencies were low in patients with anti-Sm or anti-RNP antibodies, or both, and, as stated above, were not significantly increased in patients without precipitating antibodies to RNA-nucleoprotein antigens. Thus HLA-DR3 apparently does not represent a gene that predisposes to the disease in general but rather to a subset of the disease characterised by the production of a specific autoantibody. This interpretation is indirectly strengthened by the known relationship between HLA-DR3 and primary sicca syndrome, ${ }^{32-36}$ in which anti-Ro/SSA is also a serological hallmark. ${ }^{1218}$ Moreover, it agrees with previous observations of the occurrence of HLADR3 and anti-Ro/SSA in SLE ${ }^{10} 1134{ }^{37-39}$ and LE subsets with characteristic clinical features associated with the presence of anti-Ro/SSA. ${ }^{10-13}$ When comparing our data with those of these other studies, the important common determinator is the association of anti-Ro/La with HLA-DR3, which has previously been observed in both SLE ${ }^{37-39}$ and primary Sjögren's syndrome. ${ }^{34-36} \mathrm{We}$ could not find the previously reported ${ }^{3839}$ association of anti-Ro with HLA-DR2. Moreover, in contrast with these authors, and as already previously reported by the University of Vienna and NIH groups separately, ${ }^{20} 22$ the present common study again confirms the highly increased frequency of HLADR3 in a much larger SLE population. Finally, in contrast with the findings of Alvarellos et al, ${ }^{39}$ our study showed no association of HLA-DR antigens with either frequency or levels of antinative DNA antibodies (data not shown). In additional analyses the presence of anti-Sm or RNP, or both, has been found to be significantly associated with HLA-DR4 and somewhat more strongly with the presence of DR4 or DR1, or both. Although this finding should not be overemphasised, these data and the low frequency of HLA-DR3 in this group of patients, which was also noted by Alvarellos et al, ${ }^{39}$ indicate that the expression of anti-Sm/RNP is genetically distinctly different from that of anti-Ro/La. According to our observations, patients having antibodies to both Ro and Sm/RNP tended to be positive for the DR antigens associated with each antibody specificity separately, namely DR3 and/or DR4 or DR1. It is of particular interest that the molecular structures of the related antigens Ro and La diffe from the structures of the related antigens $\mathrm{Sm}$ and: RNP, and that-as also seen in this study-anti-Le almost always occurs together with anti-Ro, whereas anti-Sm very often is accompanied by ant $\overline{\underline{Q}}$. RNP. ${ }^{34}{ }^{4-9}$ There is one report on the association of anti-RNP with HLA-DR1 in patients with mixe connective tissue disease, ${ }^{40}$ a further indication of $i$ \& different genetic association when compared with anti-Ro.

Not every patient with a specific HLA-DR antige $\vec{\theta}$ expressed the antibodies to RNA-protein antigens found to be correlated in this study and vice verso This indicates that there is either heterogeneity of the respective DR genes in the patient populatiog or, more likely, that the genes related to this production of the specific autoantibodies are not identical with but only linked to the respective $D B$ genes.

Further analyses showed that HLA-DR5 was related to the absence of the precipitating antibodie anti-Ro/SSA, anti-La/SSB, anti-Sm, and anti-RNP. and thus appeared to 'protect' against their exprese sion. On the other hand, when compared with the control population the frequency of HLA-DR2 wa significantly increased in patients with, but not i those without precipitating antibodies to Ro, La $\mathrm{Sm}$, or RNP. It is therefore tempting to speculate that genes linked to HLA-DR2 cooperate wit\$ genes linked to other DR antigens in the expressiog of specific autoantibodies in SLE. Finally, analyses of correlations between HLA-A, B, and C antigers and autoantibody specificities did not show signif cant association except of HLA-B8 with anti-Ro/La which did not exceed the association of HLA-DR (data not shown).

Our findings suggest that the association of $\mathrm{HL}$ antigens with autoimmune disease reflects the secondary role of immune response genes in defining which autoantigens will be recognised rather than a connection with the underlying primat immunoregulatory abnormality. In this regard, it $\bar{\nexists}$ pertinent and in accordance with our conclusiogs that increased frequencies of particular HLA antigens have not been observed in studies of twi or families affected by SLE; rather, similarities of clinical and serological features have bee found. ${ }^{41} 42$ Thus the predisposition to autoimmunigy may reside in the inheritance of autoimmunity genes' which may be different in individuals with different autoimmune disorders ${ }^{43-45}$; HLA-D re gion genes may then modify the expression of the disorder.

Our results in human SLE are quite analogous those of Shirai and colleagues in New Zealand mice. These investigators have shown that in the lupus- 
prone $(\mathrm{NZB} \times \mathrm{NZW}) \mathrm{F} 1$ hybrids it is the $\mathrm{H}-2^{\mathrm{z}}$ haplotype of NZW that facilitates the production of several characteristic antibodies and that this effect is independent of the underlying primary immunological abnormality. ${ }^{46}$

Taken together, the data presented provide evidence that SLE can be divided into several genetically distinct subgroups by HLA phenotyping and by determination of precipitating antibodies to RNAprotein antigens. Different autoantibody specificities are linked to different $\mathrm{D}$ locus genes of the MHC or to related genes. None of the MHC associated genes appears to be generally associated with SLE disease. The data thus speak for a pronounced immunogenetic heterogeneity of SLE with MHC control of the expression of certain serological markers. We would anticipate similar genetic heterogeneity of the underlying immunoregulatory abnormalities in SLE. These conclusions make the continued search for the genetic and environmental causes as well as for the pathogenesis of this multifaceted disorder even more challenging.

Supported by grants from the Fonds zur Förderung der wissenschaftlichen Forschung ( $P$ 4872), the Medical Foundation of the Mayor of Vienna, and the Federal Ministry for Science and Research (49.340/84).

\section{References}

1 Tan E M. Autoantibodies to nuclear antigens (ANA): their immunobiology and medicine. Adv Immunol 1982; 33: 167-240.

2 Reichlin M. In: Kelley W N. Harris E D. Ruddy S. Sledge C B, eds. Textbook of rheumatology. Philadelphia: Saunders, 1985: 690-706.

3 Harley J B, Yamagata H. Reichlich M. Anti-La/SSB antibody is present in some normal sera and is coincident with antiRo/SSA precipitins in systemic lupus erythematosus. J Rheumatol 1984: 11: 309-14.

4 Maddison P J. Skinner R P. Vlachoyiannopulos P. Brennand D M. Hough D. Antibodies to nRNP. Sm and La (SSB) detected by ELISA: their specificity and interrelations in connective tissue diseases. Clin Exp Immunol 1985: 62: 337-45.

5 Sharp G C. Irvin W S. May C M. et al. Association of antibodies to ribonucleoprotein and $\mathrm{Sm}$ antigens with mixed connective tissue disease, systemic lupus erythematosus and other rheumatic disease. $N$ Engl J Med 1976; 295: 1149-53.

6 Hendrick J P. Wolin S, Rinke J. Lerner M R. Steitz J A. Ro small cytoplasmic ribonucleoproteins are a subclass of La ribonucleoproteins: further characterization of the Ro and La small ribonucleoproteins from uninfected mammalian cells. Mol Cell Biol 1981: 1: 1138-49.

7 Takano M. Golden S S. Sharp G C. Agris P F. Molecular relationship between two nuclear antigens, ribonucleoprotein and Sm: purification of active antigens and their biochemical characterization. Biochemistry 1981: 21: 5929-35.

8 Lerner E A. Lerner M R. Janeway C A Jr. Steitz J A Monoclonal antibodies to nucleic acid-containing cellular constituents as probes for molecular biology and autoimmune disease. Proc Natl Acad Sci USA 1981; 78: 2737-41.

9 Petterson I. Hinterberger M. Mimori M. Gottlicb E. Steitz J A. The structure of mammalian small ribonucleoproteins: identification of multiple protein components reactive with anti (U1) RNP and anti-Sm antibodies. J Biol Chem 1984: 259: 5907-14.
10 Maddison P J, Provost T T. Reichlin M. Serological findings in patients with 'ANA-negative' systemic lupus erythematosus. Medicine (Baltimore) 1981; 60: 87-94.

11 Sontheimer R D. Maddison P J, Reichlin M, Jordan R E. Stastny $P$, Gilliam J N. Serologic and HLA associations in subacute cutaneous lupus erythematosus, a clinical subset of lupus erythematosus. Ann Intern Med 1982; 97: 664-71.

12 Provost T T. Arnett F C. Reichlin M. Homozygous C2 deficiency. lupus erythematosus and anti-Ro (SSA) antibodies. Arthritis Rheum 1983; 26: 1279-82.

13 Kephart D C. Hood A F. Provost T T. Neonatal lupus erythematosus: new serologic findings. J Invest Dermatol 1981; 77: $331-3$.

14 Winfield J B, Brunner C M. Koffler D. Serologic studies in patients with systemic lupus erythematosus and central nervous system dysfunction. Arthritis Rheum 1978; 21: 289-94.

15 Maddison P J, Mogavero H. Reichlin M. Patterns of clinical disease associated with antibodies to nuclear ribonucleoprotein. J Rheumatol 1978: 5: 407-11.

16 Smolen J S. Morimoto C, Steinberg A D, et al. Systemic lupus erythematosus: delineation of subpopulations by clinical, serologic, and T cell subset analysis. Am J Med 1985; 289: 139-46.

17 Alspaugh M A. Tan E M. Antibodies to cellular antigens in Sjögren`s syndrome. J Clin Invest 1975; 55: 1067-73.

18 Alspaugh M, Maddison P. Resolution of the identity of certain antigen-antibody systems in systemic lupus erythematosus and Sjögren's syndrome: an interlaboratory collaboration. Arthritis Rheum 1979; 22: 796-8.

19 Van Rood J J. De Vries R R P. Bradley B A. Genetics and biology of the HLA system. In: Dorf D M, ed. The role of the major histocompatibility complex in immunobiology. Chichester: Wiley, 1981: 59-113.

20 Reinertsen J L. Klippel J H. Johnson A H. Decker J L. Steinberg A D, Mann D L. B lymphocyte alloantigens associated with systemic lupus erythematosus. $N$ Engl $J$ Med 1978: 299: 515-8.

21 Gibofsky A. Winchester R J, Patarroyo M. Fotino M. Kunkel H G. Disease associations of the Ia-like human alloantigens: contrasting patterns in rheumatoid arthritis and systemic lupus erythematosus. $J$ Exp Med 1978; 148: 1728-32.

22 Scherak O. Smolen J S. Mayr W R. HLA-DRw3 and systemic lupus erythematosus. Arthritis Rheum 1980; 23: 954-7.

23 Cohen A S. Reynolds W E. Franklin E C. et al. Preliminary criteria for classification of systemic lupus erythematosus. Bull Rheum Dis 1971: 21: 643-8.

24 Tan E M. Cohen A S. Fries J F. et al. The 1982 revised criteria for the classification of systemic lupus erythematosus. Arthritis Rheum 1982: 25: 1271-7.

25 Van Rood J J. van Leeuven A. Ploem J S. Simultaneous detection of two cell populations by two colour fluorescence and application to the recognition of B-cell determinants. Nature 1976: 262: 795-7.

26 Baur M P. Danilovs J A. Population analysis of HLA-A. B. and $C, D R$ and other genetic markers. In: Terasaki $P$ I, ed. Histocompatibility testing. London: University of California Press. 1980: 955-62.

27 Smolen J S, Gangl A. Polterauer P. Menzel J, Mayr W R. HLA antigens in inflammatory bowel disease. Gastroenterology 1982: 82: 34-8.

28 Svejgaard A. Jersild C. Staub Nielsen L. Bodmer W F. HLA- A antigens and disease. Statistical and genetical considerations. Tissue Antigens 1974; 4: 95-105.

29 Penner E. Kindas-Mügge I. Hitchman E. Sauermann G. Nuclear antigens recognized by antibodies present in liver disease sera. Clin Exp Immunol 1986: 63: 428-33.

30 Clark G. Reichlin M. Tomasi T B. Characterization of a soluble cytoplasmic antigen reactive with sera from patients with systemic lupus erythematosus. $J$ Immunol 1969: 102: 117-22.

31 Grumet F C. HLA and disease associations. Transplant Proc 1977: 9: $1839-44$. 
32 Chused T M. Kassan S S. Opelz G. Moutsopoulos H M Terasaki P I. Sjögren's syndrome associated with HLA-Dw3. $N$ Engl J Med 1977: 296: 895-7.

33 Moutsopoulos H M. Mann D L. Johnson A H. Chused T M Genetic differences between primary and secondary sicca syndrome. N Engl J Med 1979; 301: 761-3.

34 Manthorpe R. Teppo A M. Bendixen G. Wegelius O Antibodies to SS-B in chronic inflammatory connective tissue disease. Arthritis Rheum 1982; 25: 662-7.

35 Harley J B. Alexander E L. Bias W B. et al. Anti-Ro (SS-A) and anti-La (SS-B) in patients with Sjögren`s svndrome Arthritis Rheum 1986; 29: 196-206.

36 Molina R. Provost T T. Arnett F. et al. Primary Sjögren's syndrome in men. Am J Med 1986; 80: 23-31.

37 Bell D A. Maddison P J. Serologic subsets in systemic lupus erythematosus: an examination of autoantibodies in relationship to clinical features of discase and HLA antigens. Arthritis Rheum 1980; 23: 1268-73.

38 Ahearn J M. Provost T T. Dorsch C A. Stevens M B. Bias W B. Arnett F C. Interrelationships of HLA-DR, MB and MT phenotypes, autoantibody expression, and clinical features in systemic lupus erythematosus. Arthritis Rheum 1982; 25: 1031-40.

39 Alvarellos A. Ahearn J M. Provost T T. et al. Relationships of HLA-DR and MT antigens to autoantibody expression in systemic lupus erythematosus. Arthritis Rheum 1983; 26: $1533-5$.
40 Stahl N. Johnson A H. Decker J L. Sharp G C. Mann D L.O B lymphocyte antigens in mixed connective tissue disease [Abstract]. Arthritis Rheum 1980; 23: 571 .

41 Cleland L G. Bell D A. Williams M. Saurino B C. Familiaks lupus. Family studies of HLA and serologic findings. Arthritivo Rheum 1978: 21: 183-91.

42 Reinertsen J L. Klippel J H. Johnson A H. Steinberg A D Decker J L. Mann D L. Family studies of B lymphocyte alloantigens in svstemic lupus ervthematosus. $J$ Rheumato 1982: 9: 253-62.

43 Raveche E S. Novotny E A. Hansen C T. Tjio J H. Stcinberê A D. Genetic studies in NZB mice. V. Recombinant inbre 5 lines demonstrate that separate genes control autoimmune phenotype. J Exp Med 1981: 153: 1187-97.

44 Bias W B. Mevers D A. Conley C L. Reveille J D. Wilson R W Arnett $F$ C. Evidence that autoimmunity is a Mendeliarn dominant trait [Abstract|. Am J Hum Genet 1983: 35: 77A.

45 Smolen J S. Steinberg A D. Disorders of immune regulation $A$ In: Twomey J J, ed. The pathophvsiology of human immuno? logic disorders. Baltimore: Urban and Schwarzenberg. 1982? 173-97.

46 Yoshida H. Kohno A. Ohta K. Hirose S. Maruyama N. Shirai T. Genetic studies of autoimmunity in New Zealand mice. III을 Associations among anti-DNA antibodies. NTA. and renaL disease in $(\mathrm{NZB} \times \mathrm{NZW}) \mathrm{F} 1 \times \mathrm{NZW}$ backcross mice. $J$ Immunot 1981: 127: 433-7. 